\title{
LEXICAL MEANS OF NOMINATION OF THE EMOTIONAL CONCEPT "FEAR" IN THE KAZAKH AND ENGLISH LANGUAGES
}

\author{
Dinara Ryspayeva ${ }^{1}$, Gulnara Akhmetova ${ }^{2}$, Gulsaule Kairat ${ }^{3}$, Gulgul Iskakova ${ }^{4}$, \\ Ashimova Aidana ${ }^{5}$ \\ ${ }^{1}$ Ph.D, Sh. Ualikhanov Kokshetau University, Kazakhstan, goldensunrise@mail.ru \\ ${ }^{2}$ MSc, Sh. Ualikhanov Kokshetau University, Kazakhstan, gulnarakzkk@gmail.com \\ ${ }^{3} \mathrm{Ph} . \mathrm{D}$, Sh. Ualikhanov Kokshetau University, Kazakhstan, gulsaule kairat@mail.ru \\ ${ }^{4} \mathrm{MSc}$, Sh. Ualikhanov Kokshetau University, Kazakhstan, g.ristina@mail.ru \\ ${ }^{5}$ MSc, Sh. Ualikhanov Kokshetau University, Kazakhstan, aidana nurbaeva@mail.ru
}

\begin{abstract}
This study presents the nominations of the emotional concept "fear" on the material of the Kazakh and English languages. The means of linguistic representation of the concept are analyzed on the basis of the definitions of the main lexemes in explanatory dictionaries, dictionaries of synonyms and examples from fiction. Comparative analysis of the concept identifies the national-cultural specifics and peculiarities of the perception of the concept. Lexical means of nomination in the Kazakh and English languages reflect physiological processes at the moment of experiencing the emotion, the reasons, intensity and subsequent emotional state of a person. The relevance of this research is determined by the modern general theoretical problems of linguistics, its interest in the problems of the interaction of language, thinking and culture, also by the focus on the study of fragments of the picture of the world through their linguistic representations. Fear is one of the basic emotional concepts that make up the core of the linguistic worldview. Basic emotions are universal, so are emotional concepts. However, emotional concepts are characterized by national and cultural specificity, which is reflected in the semantic differentiation associated with the assessment and comprehension of the people. Research prospects consist in further study of the structure and semantics of the concept "fear" ("қорқыныш/ fear"), in a more in-depth study of complex studies of the concept's verbalization in linguistic consciousness.
\end{abstract}

Keywords: cognitive linguistic, ethnic identity, intercultural communication, folklore, national and cultural specifics.

\section{INTRODUCTION}

The concept "fear" in different linguistic cultures draws the attention of many researchers, the reason for this is the fact that fear is one of the basic emotions of a human being. Fear is based on one of the most powerful instincts - the instinct of self-preservation, which encourages a person to defend and save. Fear is an emotion, and every person regardless of ethnicity, religion, or social affiliation has emotions. Similarities and differences in linguistic nominations of the concept in a comparative aspect are of particular interest for research. Even though the concept belongs to the basic ones, each linguistic culture has its own perception, comprehension, and assessment of this emotion. This is one of those concepts that guide the perception and understanding of reality, while linguistic activity is focused on a person and reflects reality through its perception by a person.

The anthropocentric paradigm of modern linguistics shows interest in any manifestation of the human factor 
in the language and expands the possibilities of linguistic research because it supposes the study of a language from different angles. Within the framework of the anthropocentric paradigm, language is considered in connection with human cognitive activity. The tendency towards the convergence of scientific disciplines arisen at the junction with linguistics tends to a comprehensive and multi-aspect analysis of the phenomena of language and speech.

\section{THEORETICAL FOUNDATION OF THE RESEARCH}

Investigating the relationship between the conceptual and linguistic pictures of the world, linguists are trying to establish how concepts are formed. Scientists identify a number of basic cognitive categories - concepts that are universal since they reflect a single cognitive process. Taking into consideration different points of view of defining the term "concept" (Askoldov, S.A 1997, p. 267-89, Frumkina, R.M. 1995, Likhachev, D.S. 1997, Maslova, V.A. 2001, p. 208, Telia, V.N. 1996, Vezhbitskaya, A. 1996,), we note that the concept is understood as "a quantum of knowledge, a rubric of the cognitive division of the continuum, information that has been comprehended in terms of its value and emotionality. A concept combines meanings of many lexical units and is realized not only in a word, but also in a phrase, utterance, and text. The definition of the concept has a wide range of opinions due to the fact that the concept has a multidimensional, far from the static structure and includes linguistic, cultural, psychological, social aspects. There are various methods for describing a concept in modern linguistics. The use of certain research methods and techniques in each specific case depends not only on the complexity of the concept but also on the goals and objectives. In the present study, a contrastive analysis of the concept of "қорқыныш / fear" was used on the materials and examples of the Kazakh and English languages. The research aims to determine the differences between the concept and the meaning of the word, to identify national specifics.

There is a universal and ethnonational elements in the culture of each nation, so in the semantics of each language there is a reflection of both the general, universal component of culture and the original component of a particular nation. This fundamental unity of the human psyche is manifested at different levels of the semantic organization of languages.

A language is not only an instrument of culture but a tool (means) of emotions. This multidimensional interaction of a language, a culture, and emotions manifests itself in different ways. In linguistic semantics, there is not only a common human cultural component but also a national, unique one. Therefore, cultural concepts, being national in spirit, can be untranslatable into other languages, which explain the linguistic lacunarity. This lacunarity is especially noticeable in the sphere of human emotions, both in their nomination and in the means of their expression.

What is fear from the point of view of psychology? Fear is an emotion that arises in situations of threat to the biological or social existence of an individual and is aimed at a source of real or imagined danger. An effective mental state of anticipating danger, in which a real danger threatens from an external object, and a neurotic one from the demand of attraction. Unlike pain and other types of suffering caused by the real action of dangerous factors, it occurs when they are anticipated. Depending on the nature of the threat, the intensity and specificity of the experience of fear vary in a fairly wide range of shades: alarm, dismay, fright, fear, horror. If the source of the danger is not identified or not recognized, the resulting condition is called alarm.

\section{DISCUSSIONS}

The study and comprehension of the essence of fear as a phenomenon of human existence is rooted in the depths of the historical and philosophical tradition associated with antiquity, even then there were attempts to show all the variety of forms of fear and to comprehend them from the point of view of one or another teaching. In the philosophical understanding, fear is a vague and indefinite fear that does not have a real or actual object but only intensifies from this. In the absence of real danger to fight or escape from, fear takes on particularly sinister forms, leaving no room for resistance. Is it possible to fight against nothing? Is it possible to run away from something that does not exist or not yet? Fear is an all-encompassing and at the same time pointless feeling that acts on a person like a stranglehold. The body weakens from fear, and the soul is lost.

As an emotional concept, the concept "fear" is distinguished by additional emotive characteristics, which are reflected in its lexical nomination. According to N.A. Krasavsky (Krasavsky, N.A. 2001,p. 495), word (lexeme) and super word (word combinations) nominations in the analysis of emotive concepts are the most informative since they serve as a way of generating, developing, and storing meanings.

In the Kazakh linguoculture the concept "fear" is represented by the lexeme "қорқыныш" in the English linguoculture the lexeme "fear". The analysis of dictionary definitions, lexical compatibility of the key lexeme, 
analysis of synonyms were used to describe the core of the concept "қорқыныш / fear". During the analysis of such explanatory dictionaries of the English language Practical English Dictionary (1995), Webster's Third New International Dictionary, Webster's New Practical Dictionary (1953), Webster Universal Dictionary (1977), The New Encyclopedia Britannica (15th edition 2006), Courtney R. Longman Dictionary of Phrasal Verbs (Courtney, R.,1983), Oxford Advanced Learner's Dictionary of Current English (Hornby A.S.,p. 674), it was revealed that 10 nouns most accurately convey the meaning of the lexeme "fear" - these are alarm, awe, consternation, dismay, fright, horror, terror, trepidation, panic, dread.

Based on the analysis of the dictionary definitions of the explanatory dictionaries of the Kazakh language, 5 words were identified that convey various markers of the lexeme «қорқыныш»: сес, шошу, абыржу, үрей, зәре. However, such lexemes as cec, зәре more accurately convey different states of fear in such combinations as сескенді, сес көрсетmі, зәре құты қалмады, зәресі ұшты, etc.

Different lexemes and different lexical-semantic variants of lexemes verbalize different signs of the main concept. The core of the concept "fear" in the linguistic picture of the world based on the analysis of key lexemes, synonyms can be represented as follows:

- Feeling that arises when a person is frightened, is afraid of something;

- Emotion arising in conditions of biological or social threat;

- Fear protects a person, warns of danger;

- In the social development of a person, fear is considered as one of the methods of influence, for example, as the main factor in punishment. In a society, a person is afraid of condemnation and this formed fear of condemnation is a factor that regulates human behavior.

\section{LEXICAL MEANS OF NOMINATION OF THE EMOTIONAL CONCEPT “FEAR”}

The analysis of explanatory dictionaries showed that the dominant factor in the lexeme alarm is the factor of unexpectedness of this state ("sudden feeling of fear or worry") and, as a consequence, anticipation of danger, awareness of danger. The lexeme alarm conveys a state of confusion, excitement: "There was a certain alarm provoked by some people from outside the town" (Doyle Conan A. The Scandal in Bohemia); "The alarm made people run away and hide" (Allende I. The House of the Spirits).

The lexeme абыржу is analogous to the lexeme alarm in its semantic meaning in the Kazakh language. Based on the analysis of the explanatory dictionaries of the Kazakh language, it was revealed that this lexeme conveys a state that in itself is already the cause of a feeling of fear. «Халыққа, яғни қарапайым адамдарға мұндай жағдайда көп абыржып қажеті жоқ. Өйтпеген жағдайда қаржы алаяқтығына тап болып, теңгенің бағамын жаңадан белгіленген мөлшерден әрі орынсыз көтеріп жатқан ақша айырбастау пункттеріне жем болып қалуы мүмкін» (Alipbay S. "Mundayda kup abyrzhyp kazheti zhok").

The lexeme dismay conveys the strongest feeling of fear. In such a state of numbing fear, a person cannot make a decision, soberly assess the situation. The lexeme dismay, in comparison with others, conveys very strong intense feelings that are associated with the experienced emotional state: "The curio shop? - she asked in dismay "(Maugham Somerset W. The Painted Veil).

The dictionary of synonyms of the Kazakh language also gives the lexeme cec, which has the following meanings: айбат, ызғар (fear, formidable look, threat, threatening) - сескен (1. Жасқаншақтап қорқу, қаймығу; 2. Көңілге күдік алу, қауіптену), сескенгіш (сескеніп қалғыш, күдік алғыш), сескенушілік (қаймығушылық, қорқушылық), сескеншек (жасқаншақ, қорқақ) фрормаларында кездеседі: «Халилур Рахман - Ибраһим пайғамбардан туралық үшін жан қиюды үйренді. Көңілдерінің көктем шағында, қылшылдаған жас күнінде туралық үшін отқа да түсті аянбай. Қорқу жоқ. Сескену жоқ.» (А. Auezhanuly. They were stars). This lexeme reveals the external manifestation of the emotional state, which is reflected in external signs.

An unexpected strong emotional state is conveyed by the lexeme fright in the English language. This is an emotional state generated by a feeling after experiencing fear or danger. The girl couldn 't recover from the fright which she got at the sight of a huge snake» (Doyle Conan A. The Scandal in Bohemia), "And cholera: I should be frightened out of my wits» (Maugham Somerset W. The Painted Veil). This condition is very clearly manifested externally "His expression was sullen, but she had a notion that he was frightened» (Maugham Somerset W. Theatre), "... his direct gaze gave her such a fright that she smothered a cry" (Maugham Somerset W. The Painted Veil). It should be noted that only this lexeme fright reflects not only the feeling of 
impending danger, but also the state after experiencing it.

In the Kazakh language, the equivalent is the lexeme wowy, which is used only as a perfective verb зәресі ұшу, қорқу, үрейлену, кенет үрку. Шошу - a reflex reaction, sudden state, which can be caused not only by a sense of danger, but also from surprise, can also be used in the meaning of excitement: «Онда күйеуіңізге пәленбай мың кіріс жазамыз, - деп жігіт алдындағы ақ параққа екі орынды санға үш нөлді тіркеп жазып қойды. Мұқыштың әйелі шошып кетті. - Ойбай-ау, мен оны жұмыссыз қалды деп тұрмын ғой. Пәленбай мың кіріс жазғаның не?» (M. Sembaykyzy. Song about benefits).

Horror is an emotional state that often arises under the influence of a certain factor, therefore it can be considered as something inherent in the personality and even in some cases, characteristic: "He lived in horror of being recognized and arrested» (Nolan, R. The Yard). At the same time, one of the factors of this state can be called loath, disgust, repulsive state: «He said that during those three years he had seen such terrible things that had a horror of his fellow-men and wished never to live with them again» (Maugham Somerset W. Lion Skin).

In the Kazakh language, the lexeme Ypeŭ is used, but the distinguishing feature from the English language is that negative meaning is not used with this lexeme. Үрей is a complex state, in the dictionary of psychological terms the following definition is given: «Үрей (gr. panihon —awakens a feeling of fear) - fear, panic caused by real or imaginary danger. Such fear reduces the psychological emotional state of a person, slows down the processes of perception, enhances the processes of imitation, leads to thoughtless behavior, suggestibility. Derivatives from this lexeme are: үрейленушілік, үрейлі, үрейсіз, үрейшіл, үрейшілдік. «Аулаға шығып таза аұа жұтып, самал желге сүйсініп жұлдызбен айды тамашалап рахаттанып тұрып едім бойымды үрей билеп кетті» (J. Nurbek). This is a feeling that gives rise to real and fantastic fear, as a mechanism that convinces that the danger really exists and encourages active action.

Another synonym that reveals the manifestation of a sense of fear in English is the lexeme consternation. The reason for this condition is the awareness of an impending threat. In dictionaries, the lexeme consternation is described as a state in which a person loses control, becomes powerless, helpless, bewildered and incapable to act. "They were looking at each other in consternation, and neither knew what to do» (Hardy T. Tess of the D'Urbervilles). However, this state of a person can be caused by the awareness of danger: "To our consternation the train rushed on toward the burning bridge» (Allende I. The House of the Spirits).

Terror - used in the meaning of "very strong fear", the cause of the appearance of which is an absorbing, uncontrollable emotion, associated with a threat to a human life, fear of the incomprehensible. In dangerous situations to health such fear has a protective function, a kind of response from the body, which can cause unconscious behavior up to panic: "The child's terror of the dark was something we tried to fight down» (Williamson, J.N. Best of Masques).

The given examples of lexemes consternation, terror, revealing the state of fear in the English language are equivalent to the lexeme зәре. In the Kazakh language, the word зәре means the strongest emotional stress arising from fear. The explanatory dictionary gives the following definition: 3əpe - (panic, fear), зәреci зәр түбіне кетті, зәресі қалмады, зәре - құты қашты (қатты қорықты, үрейі қашты). In ancient times, the Turki said that the soul must be protected. When a person was very frightened, the Kazakhs said«зәрем қалмады, құтым қашып кеті», phrase «зәре-құты қалмады» means «жаны қалмады, жаным шығып кете жаздады», i.e. the soul went into his heels, almost died of fear.

The lexeme awe conveys a meaning unique to English. This is a special emotional state, which caused not by a sense of danger, but by misunderstanding, surprise, a mixture of feelings, both negative and positive: "....beside the awe of the beauty which she had caught the glimpse of that day, their own affairs were trivial» (Maugham Somerset W. The Painted Veil). Often this lexeme is used in the meaning of "reverential fear" of an inexplicable, difficult to comprehend, as before the Almighty, the inexplicable greatness of beauty and power: "She was regarded by all that dwelt there with love certainly and admiration, but also with awe and not a little dread» (Maugham Somerset W. The Painted Veil). If, on the one hand, awe reveals the inner state of a person ("But Kitty, she knew no why, was filled with awe" (Maugham Somerset W. The Painted Veil), then on the other hand, it can be considered as a power that which inspires such feeling and creates this effect: "If it had not been terrifying, it would have been awe-inspiring to see a great fir-tree, sixty feet high, blazing like match-wood" (Maugham Somerset W. Lion Skin). There is no lexeme in the Kazakh language that conveys such an emotion.

In accordance with the meaning of the lexeme verbalizing the concept "fear" in English they can be used not only with a negative connotation, but also with a positive one: 
Table - 1 Positive and negative connotations of the concept "fear" in English

\begin{tabular}{|l|l|}
\hline \multicolumn{1}{|c|}{ Positive connotations } & \multicolumn{1}{c|}{ negative connotations } \\
\hline$\square$ awfully/terribly kind & awfully dull \\
$\square$ awfully/terribly young & awfully anxious \\
$\square$ awfully hospitable & frightfully nervous \\
$\square$ frightfully handsome & horribly painful \\
$\square$ terribly attractive & terribly disappointed \\
$\square$ terribly sweet & \\
$\square$ terribly good-looking & \\
\hline
\end{tabular}

\section{CONCLUSION}

The intensity of the emotional experience of fear in the English language is conveyed through semantic meanings. To convey the degree and depth of the emotional state in colloquial speech and in fiction, adverbs and adjectives in many cases are used together with interjections: Awful!, Terribly interesting, terribly sorry, etc. "But every now and then she started to cry again, far from the depths of her subconscious surged up recollections that were horribly painful» (Maugham Somerset W. Theatre).

In the Kazakh language distinction and different shapes of fear and intensity of a person's emotional state are conveyed with the help of degrees of comparison of adjectives. But what is distinctive for the English language is that it contains adjectives that reflect the presence of fear or its absence: fearful-fearless. The analysis of lexical means showed that in the English language there are two times more lexemes reflecting the concept "fear" than in the Kazakh language.

It should be noted that in the Kazakh language there are no lexical nominees expressing different facets of fear, transmitting feelings of anxiety before or after a given state, but the lexical series which convey the intensity of sensations from intensive and strong to weak are widely represented. The Kazakh people are characterized by a trait of emotional restraint and a sharp transition to an emotional outburst, which can be characterized by the different intensities of manifestations. The analyzed lexical units reflect the reason, duration, intensity and make it possible, thus, through the analysis to highlight the gradation of the emotional state. There is a common component in the semantic structure of the analyzed lexemes, and the selected semantic features are in a functional relationship with each other.

Thus, the main meaning of the lexemes reflecting the concept "fear"/"қорқыныш" in the Kazakh and English linguocultures coincides - this is an emotional state, a natural reaction to danger, an unpleasant sensation. However, the national and cultural specificity is reflected in the semantic differentiation associated with the assessment and understanding of the people of the emotions of fear, which are reflected in the context, wide use of meanings.

\section{REFERENCE LIST}

Askoldov, S.A. (1997) Concept and word. Russian literature. From the theory of literature to the structure of the text. Anthology, ed. prof. V.P. Unsigned. M. Academia, 267-89.

Comte Sponville, A. (2012) Philosophical Dictionary. Moscow: Eterna,.

Courtney, R. (1983) Longman Dictionary of Phrasal Verbs. Longman.

Frumkina, R.M. (1995). Does the modern linguistics have epistemology? The language and science of the end of the XX cent. / Ed. by StepanovY.S. M: IYAZ RAS, Russian State Humanitarian University.

Golovin, S.Yu. (1998) Dictionary of the Practical Psychologist. Minsk: Harvest

Hornby, A.S. Oxford Advanced Learner's Dictionary of Current English. Oxford University Press.

Kazakh tilinin tusindirme sozdigi (2008) Dyk-Press. Almaty, 968. 
Kazakh udebi tilinin sozdigi. 10-volume (2011). Almaty.

Kazakh udebi tilinin sozdigi. 4th volume (2007). Almaty: Arys,.

Kazakh tiliniң қуsқаsha etymologylyқ sozdigi. (1966). Almaty: Kazakh SSR-nyn Gylym Baspasy, Kazakh tilinin tusindirme sozdigi (1977). Almaty..

Krasavsky, N.A. (2001) Emotional concepts in German and Russian linguistic cultures. Monograph. Volgograd: Change, 495.

Likhachev, D.S. (1997). Conceptual sphere of the Russian language. Russian literature. Anthology. Moscow: Academia.

Maslova, V.A. (2001) Linguoculturology: study guide for students for higher institutions. Moscow:

Academy. 208.

Maslova, V.A. (2005) Cognitive Linguistics: A Study Guide. Minsk: TetraSystems, 256.

Popova, Z.D., Sternin, I.A. (2003) Essays on Cognitive Linguistics. Voronezh: Istoki,191.

Practical English Dictionary (1995) Second Edition. Oxford University Press,674.

Suleimenova, E. D., Shaimerdenova, N. Zh. (2002)Dictionary of sociolinguistic terms. Almaty: Kazakh University, 170.

Shaklein, V. M. (1998) Linguocultural situation: structure and issues of historical reconstruction. Thesis..

Shakhovsky, V.I. (1996) Emotional Cultural Concepts: Parallels and Contrasts. Linguistic personality: cultural concepts. Volgograd.

Telia, V.N. (1996). Russian phraseology. Semantic, pragmatic and linguistic - cultural aspects. M.: School "Languages of Russian Culture".

The New Encyclopedia Britannica. - Encyclopaedia Britannica 15th edition (2006) // www.britannica.com

Vezhbitskaya, A. (1996). Language. Culture. Cognition. Moscow: Russian dictionaries.

Webster's Third New International Dictionaryby Philip Babcock Gove (Editor)

Webster's New Practical Dictionary (1953) G\&C Merriam Co.

Webster Universal Dictionary (1977) Consolidated / Webster's Universal Press, Unabridged edition. 